\title{
STEROWANIE POPRZECZNE BEZZAŁOGOWYM STATKIEM POWIETRZNYM ZA POMOCA ZABURZACZY WARSTWY PRZYŚCIENNEJ
}

\author{
Kamila Wygodzka, Andrzej Gronczewski \\ Politechnika Wroctawska, Katedra Kriogeniki i Inżynierii Lotniczej, Wrocław \\ e-mail: kamila.wygodzka@pwr.edu.pl; andrzej.gronczewski@pwr.edu.pl \\ TOMASZ KURZYNOWSKI \\ Politechnika Wrocławska, Katedra Technologii Laserowych, Automatyzacji i Organizacji Produkcji, Wrocław \\ e-mail: tomasz.kurzynowski@pwr.edu.pl
}

\begin{abstract}
W artykule przedstawiona została koncepcja sterowania poprzecznego bezzałogowym statkiem powietrznym (BSP) przy pomocy zaburzaczy warstwy przyściennej, opisana szerzej w pracy magisterskiej pt. „Badanie efektywności sterowania samolotem za pomocą wirów krawędziowych" [3]. Przeprowadzony został przegląd aktualnego stanu wiedzy w temacie sposobów generowania wirów krawędziowych i opracowane zostały rozwiązania mechanicznych turbulizatorów dla modelu o skrzydle prostokątnym. Omówione zostały także wyniki badań eksperymentalnych przeprowadzonych w tunelu wodnym dla modeli wyposażonych w układy turbulizujacce z elementami aktywnymi oraz pasywnymi. W podsumowaniu zaproponowano możliwe dalsze kierunki rozwoju badań nad niekonwencjonalnymi sposobami sterowania.
\end{abstract}

Słowa kluczowe: generatory wirów, sterowanie warstwą przyścienną, niekonwencjonalne sterowanie BSP

\section{Wstęp}

Obecnie niewielkie bezzałogowe statki powietrzne konstruowane są z wykorzystaniem klasycznego sterowania powierzchniami nośnymi płatowca, tj. lotki, ster wysokości, ster kierunku, interceptory itd. Jednakże lot modeli typu $\mathrm{MAV}^{1}$ ze względu na małe gabaryty oraz znacznie mniejsze prędkości niż te występujące przy ruchu dużych SP, odbywa się w obszarze prędkości podkrytycznych. Jednym z podstawowych problemów aerodynamiki małych prędkości jest zjawisko odrywania strug od opływanych powierzchni. Pojawia się ono wskutek zbyt małej energii opływu powietrza, powodując znaczny spadek doskonałości aerodynamicznej, a w efekcie wzrost siły oporu i zmniejszenie siły nośnej płata. Kolejną kwestią związaną z lotem podkrytycznym jest niska efektywność klasycznego rozwiązania sterowaniem statkiem powietrznym. Przy niewielkich prędkościach, przy jakich porusza się mikro-samolot, konieczne bowiem jest użycie dużych powierzchni sterowych, co niekorzystnie przekłada się na dynamikę lotu. Jednym z pomysłów na rozwiązanie tych problemów, bardzo popularnym wśród badaczy w ostatnich latach, jest zastosowanie sterowania warstwą przyścienną (BLC).

\footnotetext{
${ }^{1}$ MAV - ang. Micro Aerial Vehicle - bezzałogowy statek powietrzny klasy micro, czyli posiadający masę do $5 \mathrm{~kg}$, a co za tym idzie stosunkowo niewielkie rozmiary.
} 


\section{Wprowadzenie do sterowania za pomocą wirów krawędziowych}

\subsection{Sterowność statku powietrznego}

Sterowność z definicji określana jest jako zdolność statku powietrznego (SP) do zmiany parametrów lotu zgodnie z wolą sterującego. Rozważa się ją względem układu współrzędnych zamocowanego w środku masy SP. Układ ten składa się z umownych, wzajemnie prostopadłych osi $x, y, z$ przedstawionych na rysunku 1.

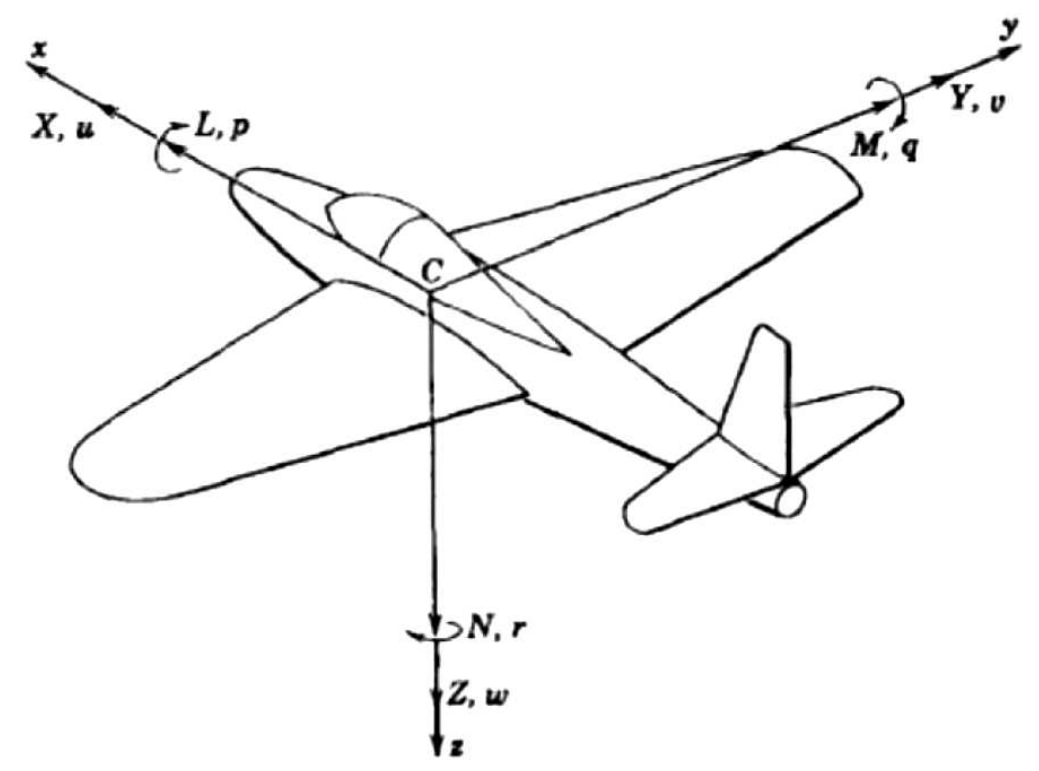

Rys. 1. Osie statku powietrznego [1]

Oś z, przechodząca od góry kabiny do podwozia, to oś normalna, względem której działa moment odchylający $N$. Oś poprzeczna $y$, przechodząca przez końcówki płata jest osią, względem której rozpatruje się pochylanie SP. Ostatnią z osi jest oś podłużna $x$, przechodząca przez środek symetrii samolotu od nosa do ogona. $Z$ wagi na działający względem niej moment przechylający $L$ nazywana jest czasami osią przechylenia bądź toczenia. Ruch względem osi podłużnej jest głównym przedmiotem zainteresowania w poniższych rozważaniach.

\subsection{Sterowanie za pomocą zaburzania przepływu}

Sterowanie samolotem opiera się na manipulacji wielkością sił aerodynamicznych, głównie siły nośnej występującej na konkretnych powierzchniach. Jej powstawanie bezpośrednio łączy się z różnicą ciśnień pojawiająca się między górną a dolną powierzchnią profilu. Przy lotach z prędkością podkrytyczną strugi w dolnej części płata, za pomocą występującego tam nadciśnienia, dociskane są do ścianki, co zapobiega ich oderwaniu. Przeciwne zjawisko ma miejsce w górnej części, gdzie przepływ jest silnie uzależniony od liczby Reynoldsa. Występujące podciśnienie pogrubia warstwę przyścienną, powodując oderwanie strugi od ścianki.

Proces BLC obejmuje zakres pasywnego lub aktywnego oddziaływania na warstwę przyścienną w celu uzyskania zamierzonego efektu, takiego jak oderwanie bądź zaburzenie generujące tzw. wir energetyczny. Elementami ingerującymi w opływ są turbulatory. Ich funkcją jest wygenerowanie wirów powodujących wzrost energii przepływu, a tym samym zwiększenie odporności warstwy przyściennej na oderwanie. Zaburzacze, w związku ze swą budową, powodują opory przepływu. Jednak „dociśnięcie” strugi do powierzchni pozwala na uniknięcie znacznie większego oporu całkowitego, czego efektem jest osiągnięcie większej siły nośnej przy znacznie zmniejszonej sile oporu (rys. 2). 

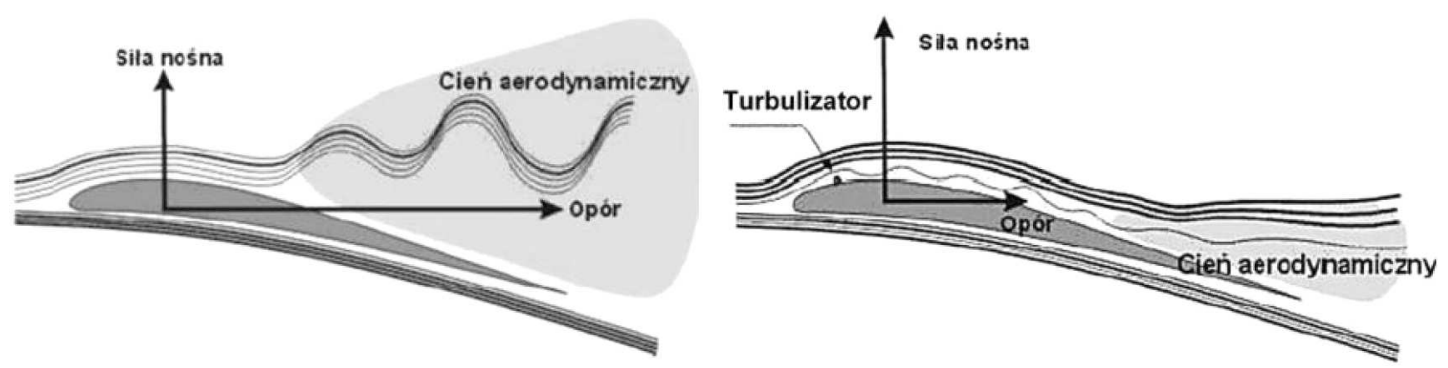

Rys. 2. Opływ skrzydła z turbulizatorem i bez [2]

Wyróżnić można dwie metody wykorzystania turbulizatorów do sterowania przepływem. Podział dokonany możne zostać ze względu na sposób dostarczenia energii wymuszającej zmianę przepływu i przedstawiony schematycznie na rys. 3 .

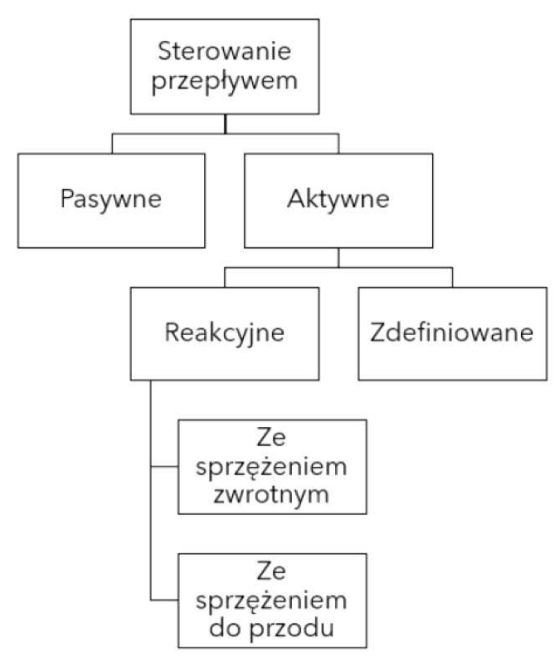

Rys. 3. Schemat reprezentujący podział metod sterowania przepływem ze względu na sposób dostarczenia energii wymuszającej zmiany przepływu [3]

Pasywne sterowanie (PFC) nie pochłania energii z zewnątrz, a wytwarzanie wirów odbywa się za pomoca oddziaływania na przepływ nieruchomo zamocowanych elementów na powierzchni opływanej. Niewątpliwym plusem takiego rozwiązania jest prostota wykonania, jednak - co widać na schemacie - nie istnieje możliwość bieżącego oddziaływania.

W przeciwieństwie do PFC aktywne sterowanie (AFC) jest metodą wymagającą dostarczenia dodatkowej energii spoza przepływu. Realizowane może to być poprzez np. nadmuch powietrza. AFC stwarza możliwość regulacji parametrów oddziaływania na warstwę przyścienną, co z kolei umożliwia wykorzystanie go nie tylko do podwyższania osiągów statków powietrznych, ale także do ich sterowania [4].

\section{Aktualny stan wiedzy na temat generatorów wirów}

Sterowanie przeprowadzane jest przy wykorzystaniu różnego rodzaju generatorów wirów, które podzielić można na generatory pasywne i aktywne.

Turbulizatory pasywne są to zwykle nieskomplikowane elementy nieruchomo przytwierdzone do powierzchni skrzydła. Wśród dostępnych rozwiązań wyróżnić można:

- nakładki o dużej chropowatości zafalowujące strugę i przyspieszające przejście w warstwę turbulentną,

- zaburzacze drutowe wpływające na nierównoległość przepływu, 
- turbulizatory otworkowe zasilane z dolnej części profilu,

- zębate nakładki mocowane za krawędzią natarcia (rys. 4).

(a)

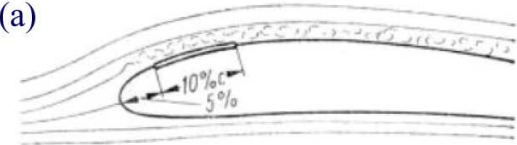

(b)

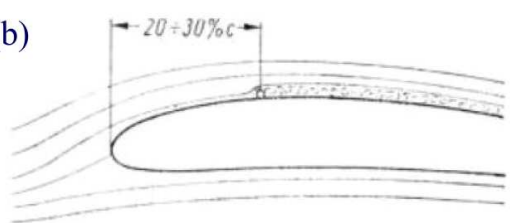

(c)

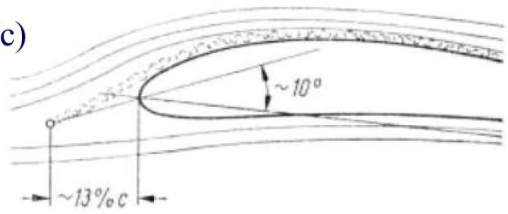

(d)

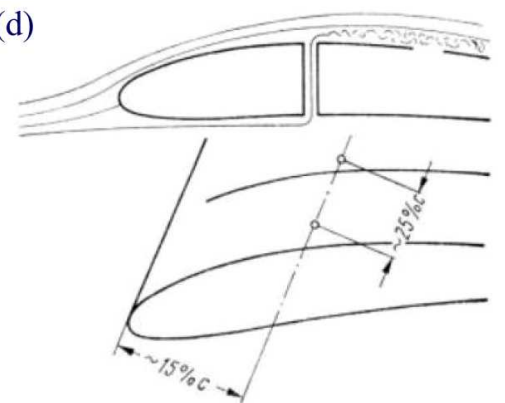

(e)

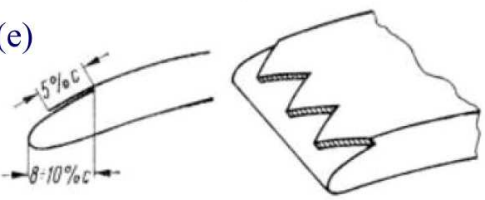

Rys. 4. Turbulatory pasywne: (a) - nakładka z papieru ściernego, (b), (c) - drutowe, (d) - otworkowy, (e) - zębata nakładka turbulizująca [2]

Przedstawione powyżej pomysły wykorzystywane są najczęściej w pasywnych układach sterowania, jednak bardzo łatwo jest je przekonstruować w taki sposób, by były elementami pasywnymi w układach aktywnych.

Drugą grupą są turbulizatory aktywne, wymagające zasilania z zewnętrznych źródeł energii. Najczęściej mają postać mikroklap, membran, mikrogłośników, dysz, grzałek bądź aktuatorów plazmowych. Układy ze sprzężeniem zwrotnym wyposażone są dodatkowo w czujniki i mikroprocesory. W konstrukcjach układów aktywnych szerokie zastosowanie znajdują nowe technologie. Szczególną uwagą cieszą się układy MEMS², w których możliwe jest zintegrowanie czujników, elementów wykonawczych i układów sterujących. Ze względu na rozmiary układy MEMS charakteryzują się bardzo małymi stałymi czasowymi umożliwiającymi sterowanie w czasie rzeczywistym.

(a)

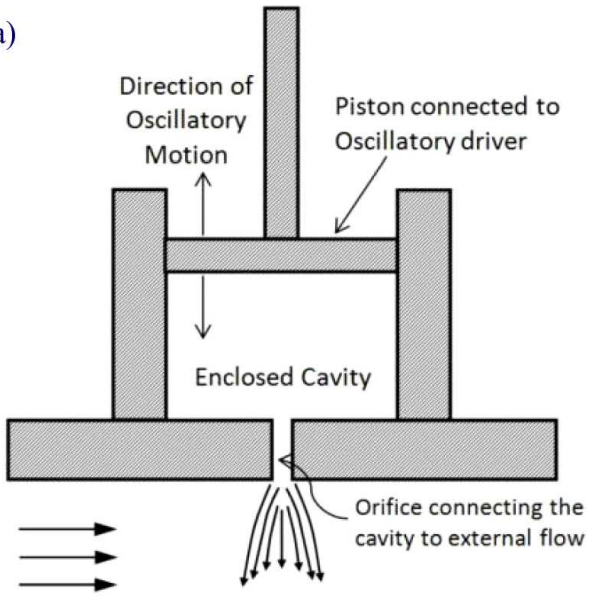

(b)

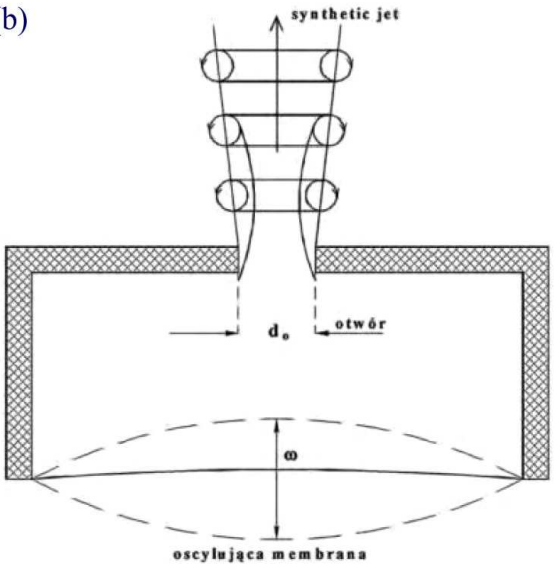

Rys. 5. Układ wykorzystujący technikę „synthetic jet”: (a) - z tłoczkiem [5], (b) - z membraną [4]

Jedną z grup generatorów aktywnych są układy sterowania przy użyciu techniki „synthetic jet” (rys. 5). Metoda opiera się na pulsacyjnym zasysaniu i wyrzucaniu strumienia powietrza

\footnotetext{
${ }^{2}$ MEMS - ang. Micro-Electro Mechanical Systems - mikroukłady elektromechaniczne o rozmiarach rzędu kilku mikronów.
} 
z otworów lub szczelin wykonanych na powierzchni opływanej. Wytwarzany strumień powstaje na skutek oscylującej powierzchni zamykającej przestrzeń tuż pod powierzchnią skrzydła. Przy dużych amplitudach oscylacji wzbudnika generowane wiry osiągają wystarczającą energię, by opuścić otwór wylotowy i nie zostać na powrót zassanym. Dzięki temu powstaje seria cyklicznych wirów, która w czasie przepływu tworzy warstwę zaburzeń dobrze przylegających do opływanej powierzchni. Układy te zasilane są z reguły za pomocą piezogeneratorów.

Jako kolejną grupę układów sterujących można wskazać układy wykorzystujące membranę. Membrana pobudzana jest za pomocą zamontowanych pod nią dodatkowych elementów. Zmiana położenia membrany może być dokonywana za pomocą ruchomej wkładki wyposażonej w zestaw żeber i wykonującej ruch wahadłowy (rys. 6). Podczas ruchu żebra wysuwają się przez wykonane w poszyciu nacięcia i wypychają elastyczne tworzywo. Kolejnym rozwiązaniem jest membrana odkształcana za pomocą rolki z kilkoma mimośrodowo zamontowanymi bieżniami (rys. 6b). Oscylacje membrany realizowane mogą być również za pomocą układu z piezogeneratorem (rys. 6c) [6], [7].

(a)

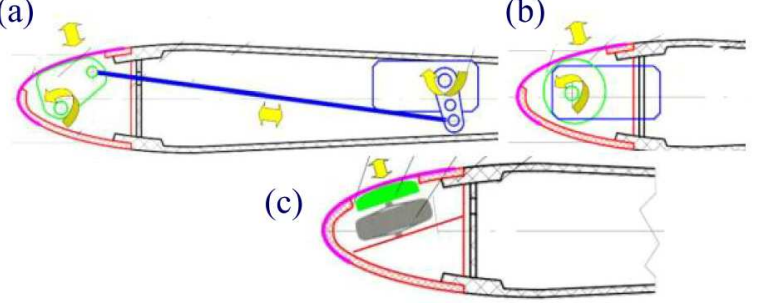

(d)

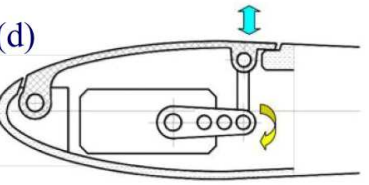

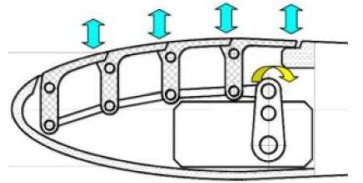

Rys. 6. Schematy układów: (a), (b), (c) - z odchylaną giętka membraną [6], (d) - z klapkami [7]

Do zaburzania warstwy przyściennej wykorzystywane są także ruchome klapki (rys. 6d). Układy takie mogą wykonywać drgania lub wychylać się jako element stały w określonych fazach lotu.

Układy membranowe oraz klapkowe zasilane mogą być zarówno poprzez serwomechanizm, który pozwala uzyskać znaczne przemieszczenia, jak i piezogenerator, cechujący się łatwością osiągania dużych częstotliwości ruchu.

Rozwiązaniem znanym od dawna jest doprowadzenie strugi z zewnątrz, która posiada energię większą od strugi opływającej profil. Szczególną uwagę takiemu rozwiązaniu poświęciła firma BAE Systems, która od kilku lat z powodzeniem bada modele sterowane za pomocą nadmuchu. Ich najnowszym osiągnięciem jest całkowite zastąpienie powierzchni sterowych układami zaprezentowanymi na rysunku 7. Sterowanie pochyleniem zrealizowane jest przez przepływowe wektorowanie ciągu. Neutralnym położeniem statku powietrznego podczas lotu jest nos skierowany do dołu - przy niewielkim wprowadzeniu powietrza bezzałogowiec osiąga pozycję horyzontalną, natomiast przy maksymalnym wdmuchu ciąg zostaje znacznie odchylony, a nos zadziera się do góry. Elementem dopełniającym sterowanie modelem jest naddźwiękowy wydmuch powietrza przez wąską szczelinę na krawędź spływu [8], [9].
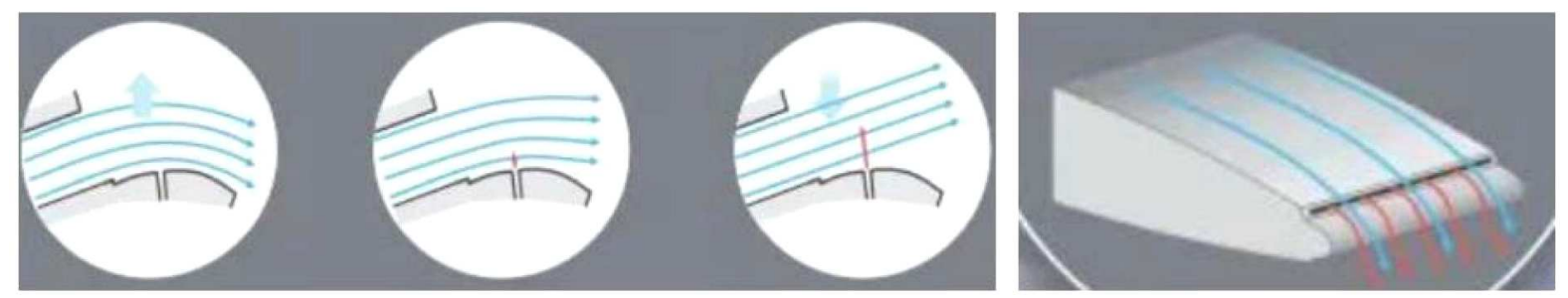

Rys. 7. Systemy sterowania bezzałogowym statkiem powietrznym MAGMA [10] 
W innym projekcie statku powietrznego powierzchnie sterowe zastąpione zostały mechanizmem kontroli przepływu przedstawionym na rysunku 8. Koncepcja opiera się na podobnej zasadzie jak w BSP MAGMA, natomiast na krawędzi spływu zamiast stałego wysklepienia zastosowany został cylindryczny pręt. W związku z mimośrodową swobodą obrotu pręta względem osi podłużnej odsuniętej od jego osi symetrii, regulacji podlega wielkość szczeliny nad i pod nim. W czasie regulacji można asymetrycznie zamknąć szczelinę dolną przy pełnym rozwarciu górnej lub na odwrót. Zrealizować można w ten sposób dwukierunkową modulację siły nośnej. W obydwu koncepcjach wprowadzana struga pobierana jest z przestrzeni za silnikiem. Efekt końcowy układów nadmuchu polega na zmianie fizycznego sterowania klapami, które oddziałuje na strugi zewnętrzne, na kierowanie przepływem wskutek doprowadzenia nowych strug zakłócających opływ [11].
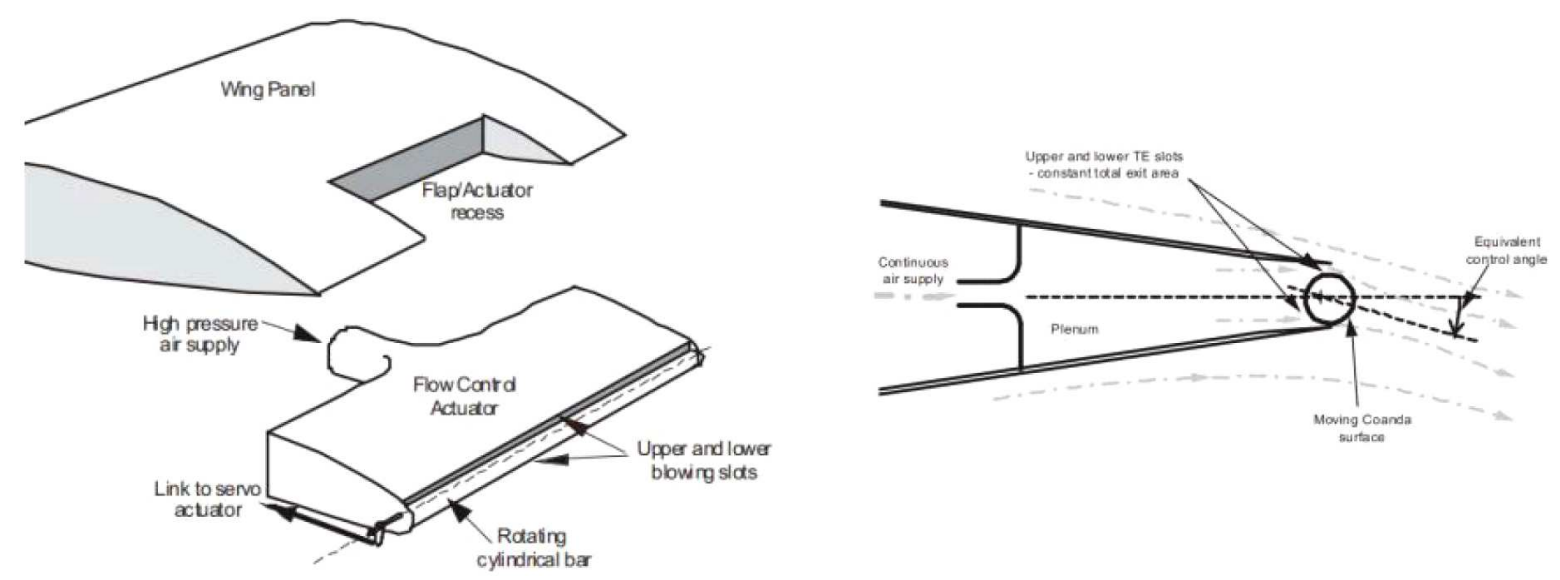

Rys. 8. Alternatywny system sterowania bezzałogowym SP Demon [11]

Jednym z ciekawszych rozwiązań konstrukcyjnych do generowania zaburzeń jest zastosowanie plazmowych wzbudników. Wykonane są z dwóch przesuniętych względem siebie w kierunku przepływu elektrod, będących cienkimi płytkami, oddzielonymi materiałem dielektrycznym, np. teflonem. Elektroda zamocowana bliżej krawędzi natarcia znajduje się na powierzchni profilu, tylna elektroda tuż pod poszyciem. Jeśli przyłożone zostanie wysokie napięcie, rzędu kilkunastu kilowoltów, to na powierzchni pomiędzy elektrodami wytworzy się obszar zjonizowanego gazu, tzw. plazma. Wynikiem niesymetryczności położenia elektrod jest przyspieszanie jonów w kierunku przepływu. Dzięki temu dochodzi do zmiany rozkładu prędkości w warstwie przyściennej i uodpornienie jej na oderwanie.
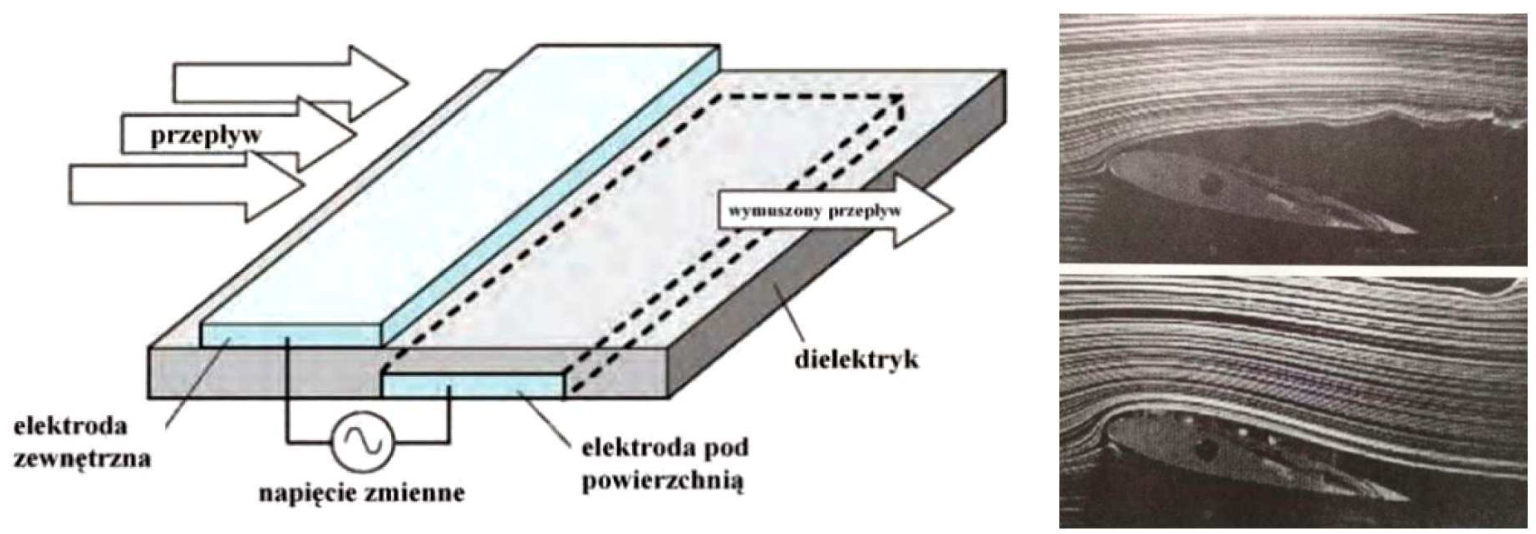

Rys. 9. Schemat sterowania przepływem za pomocą plazmowych wzbudników [4] i efekt działania wzbudnika na opływ [12] 


\section{Koncepcje turbulatorów mechanicznych}

\subsection{Założenia konstrukcyjne}

Na podstawie przeprowadzonej analizy literatury opracowane zostały założenia konstrukcyjne, jakie muszą spełniać układy generujące wiry krawędziowe. Przy ich pomocy zaproponowane zostały rozwiązania zaburzaczy do eksperymentalnego przebadania efektywności sterowania poprzecznego SP.

Przyjęte zostały następujące założenia konstrukcyjne:

- układy sterowania mają opierać się na sterowaniu aktywnym warstwą przyścienną,

- rozwiązania mają się cechować prostotą konstrukcji oraz wykonania, muszą być łatwe w montażu, obsłudze i niezawodne w działaniu,

- napęd układu zrealizowany ma być za pomocą ogólnodostępnych serwomechanizmów lub piezogeneratorów,

- projektowane rozwiązania działać mają autonomicznie i w pełni zastępować konwencjonalne sterowanie lotkami,

- wymagane jest osiąganie dużych amplitud wychyleń, w celu lepszej obserwacji zjawiska,

- możliwość montażu na krawędzi natarcia lub górnej powierzchni skrzydła.

\subsection{Opracowane rozwiązania}

Trzymając się przyjętych założeń konstrukcyjnych, przygotowano rozwiązanie układu turbulizacji w postaci powierzchni z dwoma segmentami typu makro oscylacyjnie wychylającymi się synchronicznie bądź naprzemiennie (rys. 10). Długość robocza elementów wynosi $80 \mathrm{~mm}$. Mechanizmy moga zostać zablokowane do badań w położeniu otwartym bądź wychylać się z zadaną prędkością. Układy opierają się na serwomechanizmach pozwalających na duże amplitudy wychyleń części roboczych.

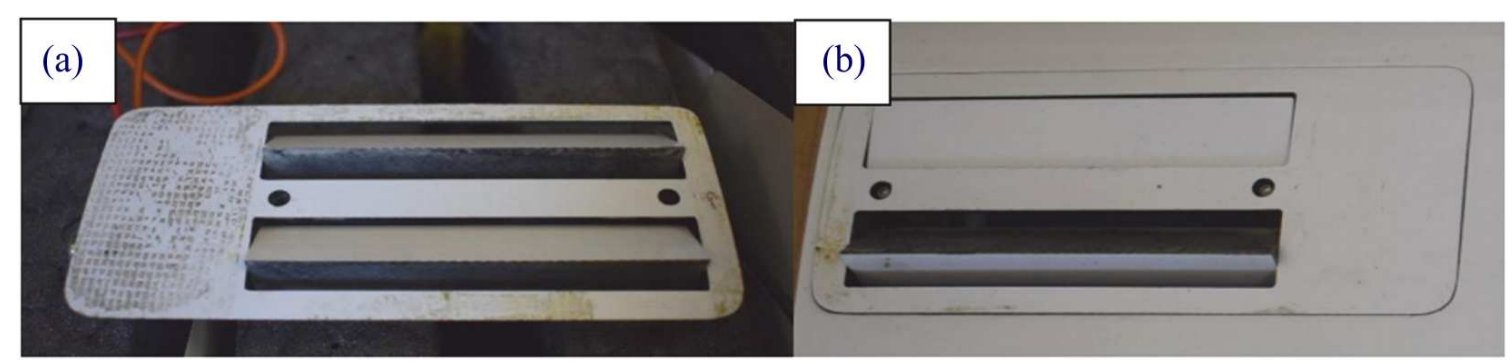

Rys. 10. Mechanizm zaburzający: (a) z dwoma elementami wystającymi, (b) z naprzemiennie wystającym jednym elementem

\section{Metodologia badań}

Sprawdzenie skuteczności działania wybranych układów turbulizujących w sposób eksperymentalny polega na zamontowaniu lub uruchomieniu zestawu generującego wiry krawędziowe tylko na jednym skrzydle i obserwację zmian zachodzących w podstawowych siłach aerodynamicznych. Działanie zaburzacza powinno spowodować zmniejszenie oporu ruchu oraz wzrost siły nośnej. Model wykazywać powinien więc tendencję do skrętu w kierunku skrzydła bez uruchomionego układu turbulizującego. Brak wystąpienia tego efektu świadczy o nieskuteczności wybranego rozwiązania. 


\subsection{Urządzenie badawcze}

Podczas wykonywania badań nad efektywnością sterowania za pomocą wirów krawędziowych wykorzystany został tunel wodny firmy Rolling Hills Research Corporation, model 2436. Długość tunelu wynosi $9260 \mathrm{~mm}$, szerokość z uwzględnieniem rury przepływowej $3922 \mathrm{~mm}$. Wysokość całej konstrukcji waha się w przedziale 2320-3500 mm, zależnie od położenia suportu - w pozycji do montażu modelu lub badań. Konstrukcję samego tunelu podzielić można na sześć sekcji, które przedstawione zostały na rys. 11 za pomocą oznaczeń A-F. Pierwsza z nich, sekcja A, to komora osadczo-wlotowa, następnie występuje sekcja B będąca elementami ustalającymi przepływ. Sekcja C to przewężenie do szerokości przestrzeni pomiarowej o wymiarach $1700 \times 550 \times 900 \mathrm{~mm}$, będącej sekcją D. Sekcja E to komora wylotowa płynu oraz sekcja F rurociąg przepływu powrotnego.

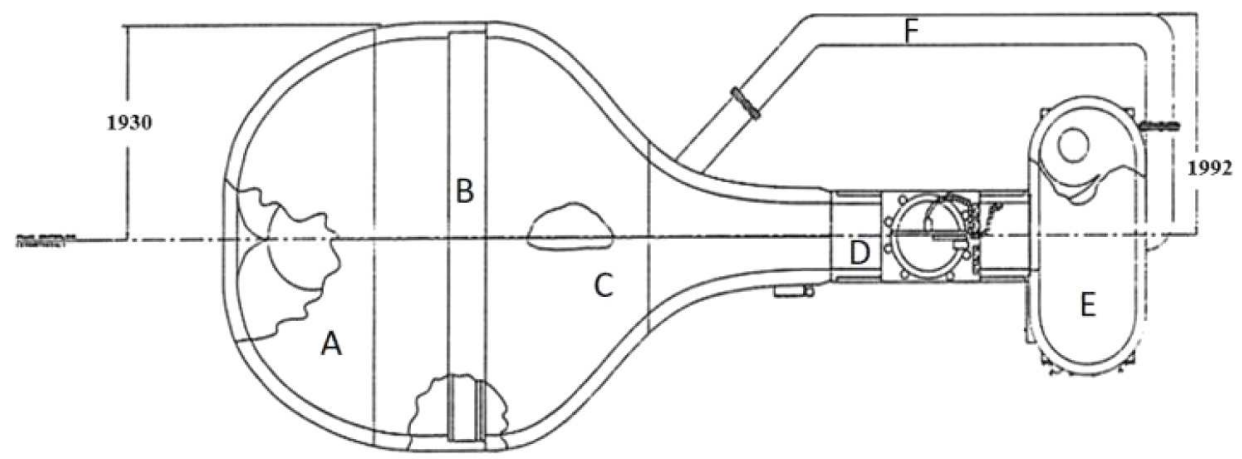

Rys. 11. Sekcje tunelu 2436 [13]

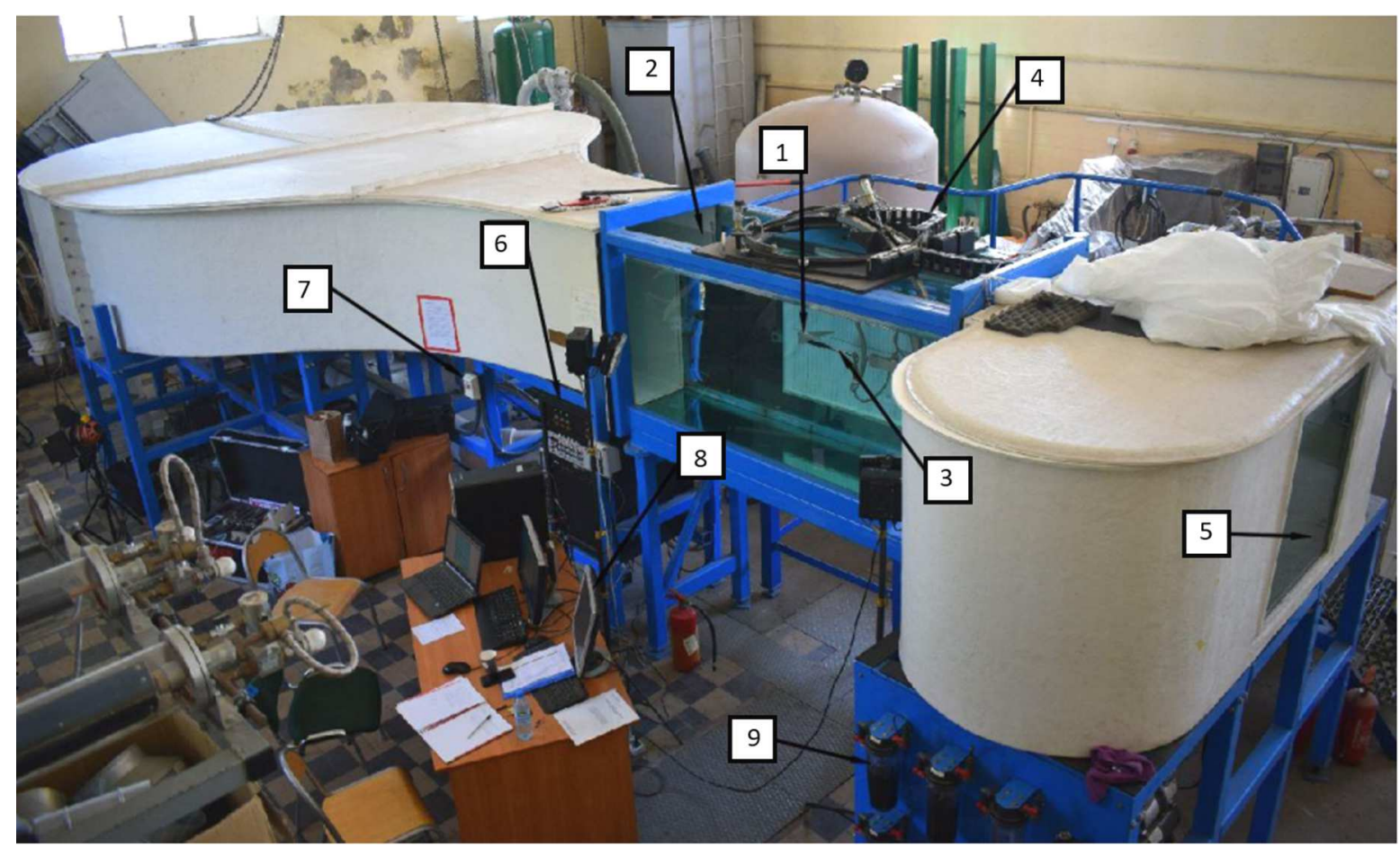

Rys. 12. Schemat stanowiska pomiarowego: 1 - model, 2 - przestrzen pomiarowa, 3 - waga tensometryczna, 4 - suport, 5 - okno ustawień przechylenia/odchylenia, 6 - panel wzmacniający, 7 - włącznik główny, 8 - stanowisko komputerowe, 9 - układ wizualizacji

Tunel działa w obiegu zamkniętym i wykorzystuje urządzenie pomiarowe w postaci wagi tensometrycznej, do której montowany jest model. Waga składa się z sekcji momentu przechylają- 
cego, dwóch sekcji momentu pochylającego i dwóch sekcji momentu odchylającego. Każda sekcja składa się z czterech 28 półprzewodnikowych czujników tensometrycznych ułożonych w mostki Wheatstone'a.

Stanowisko badawcze składało się z tunelu wodnego oraz stanowiska komputerowego wyposażonego w oprogramowanie do zbierania danych. Poszczególne elementy układu pomiarowego przedstawione zostały na rys. 12 .

\subsection{Modele wykorzystane $\mathrm{w}$ badaniach}

Do badań wykorzystano dwa modele bezzałogowych statków powietrznych typu MAV o skrzydle prostokątnym, których podstawowe wymiary przedstawione zostały w tabeli 1 . Posiadają one płat nośny o profilu David Fraser DF 101, charakteryzujący się grubością względną $\bar{g}=11 \%$ na odległości $29,1 \%$ cięciwy aerodynamicznej oraz wygięciem szkieletowej równym 2,3\% w odległości 43,5\% cięciwy [14].

Tabela 1. Wymiary charakterystyczne modeli

\begin{tabular}{|l|c|c|c|}
\hline \multicolumn{1}{|c|}{ Wymiar } & Oznaczenie & Wartość [mm] & Wartość [in] \\
\hline \hline $\begin{array}{l}\text { Srednia cięciwa } \\
\text { aerodynamiczna }\end{array}$ & $C_{a}$ & 180 & 7,09 \\
\hline Rozpiętość & $b$ & 380 & 14,96 \\
\hline Powierzchnia płata & $S$ & 68400 & 106,07 \\
\hline
\end{tabular}

Pierwszy z modeli, wyposażony jedynie w powierzchnie sterowe, posłużył do wyznaczenia porównawczych charakterystyk w konfiguracji płaskiej, z wychyloną jedną lotką oraz dwoma lotkami o przeciwnym wychyleniu. Otrzymane wyniki z badań SP były podstawą do ilościowej oceny efektywności działania zaburzaczy przepływu w stosunku do konwencjonalnej metody sterowania.

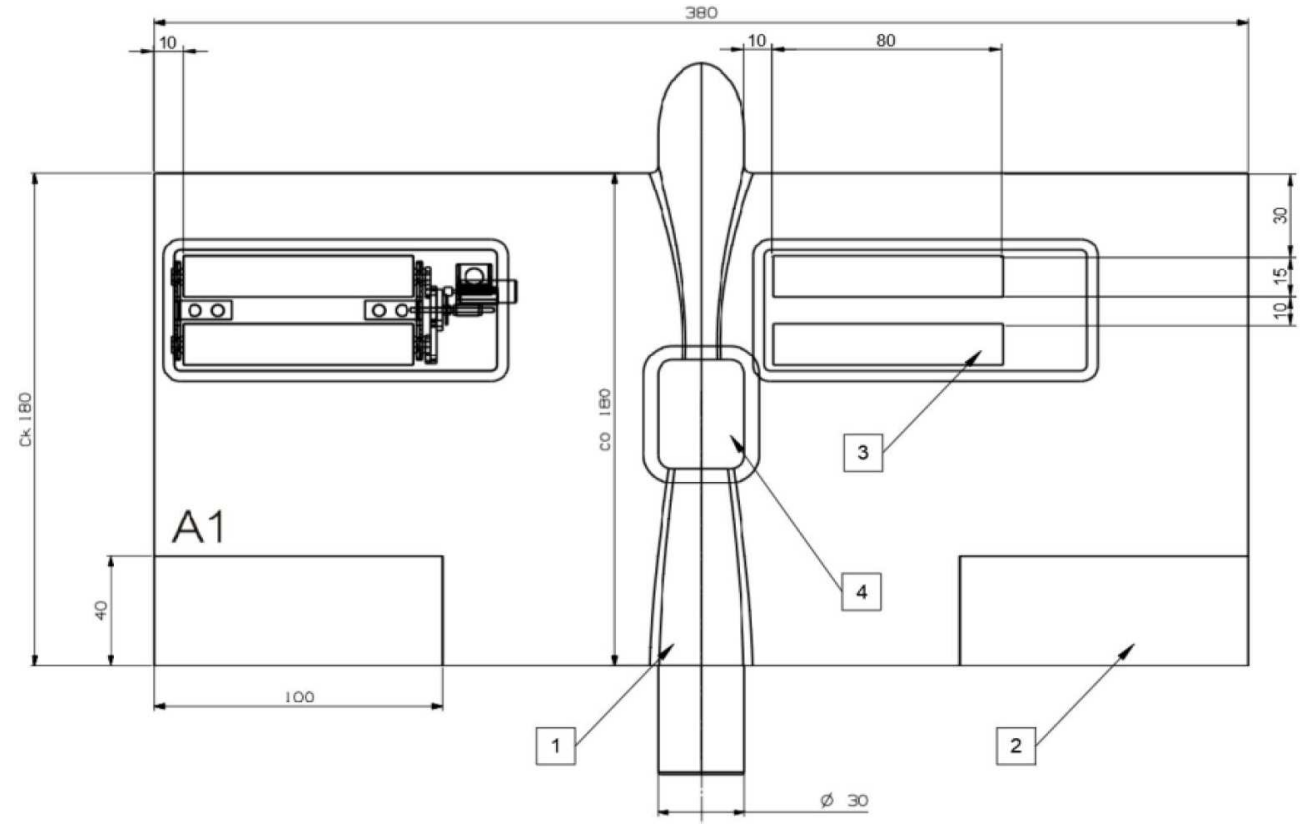

Rys. 13. Schemat modelu z układem zaburzajaccym: 1 - kadłub, 2 - lotka, 3 - turbulizator, 4 - klapka technologiczna

Drugi model (rys. 13) przeznaczony został do wyznaczenia charakterystyk z wykorzystaniem zaburzaczy przepływu. Badania przeprowadzone zostały dla trzech konfiguracji: 
- z nieruchomym turbulizatorem, posiadającym dwa elementy wystające, położonym przy kadłubie,

- nieruchomym turbulizatorem, posiadającym dwa elementy wystające, położonym przy krawędzi płata,

- ruchomym turbulizatorem zamontowanym przy krawędzi płata z naprzemiennie wychylającymi się elementami.

\subsection{Przebieg eksperymentu}

Testy modeli w tunelu wodnym wykonane zostały dla wszystkich konfiguracji przy prędkości przepływu ustawionej na $11 \mathrm{in} / \mathrm{s}(0,2794 \mathrm{~m} / \mathrm{s})$. Wybrany został test statyczny dwukierunkowy, w którym kąty natarcia oraz ślizgu ustawione zostały zgodnie z tabelą 2.

Tabela 2. Ustawienia kątów w trakcie badań

\begin{tabular}{|l|c|c|c|}
\hline \multicolumn{1}{|c|}{ Kąt } & Kąt początkowy & Skok kąta & Kąt końcowy \\
\hline \hline Natarcia $\alpha$ & \multirow{2}{*}{$0^{\circ}$} & \multirow{2}{*}{$5^{\circ}$} & $30^{\circ}$ \\
\cline { 1 - 1 } \cline { 4 - 5 } Ślizgu $\beta$ & & $-180^{\circ}$ & $25^{\circ}$ \\
\cline { 1 - 1 } Przechylenia $\varphi$ & \multicolumn{3}{|c|}{} \\
\hline
\end{tabular}

W trakcie badań punkt referencyjny wagi tensometrycznej znajdował się w okolicy $40 \%$ cięciwy aerodynamicznej. Do wyznaczenia wartości sił aerodynamicznych posłużono się następującymi wzorami $[15]$

$$
c_{z}=c_{N} \cos \alpha \quad c_{x}=c_{N} \sin \alpha
$$

gdzie: $c_{z}$ - współczynnik siły nośnej, $c_{x}$ - współczynnik siły oporu, $c_{N}$ - współczynnik siły normalnej.

\section{Wyniki}

Na wykresie zależności współczynnika siły nośnej od kąta natarcia oraz biegunowej (rys. 14) widać, że krytyczny kąt natarcia modelu wypada w okolicy $15^{\circ}$. Po przekroczeniu tego kąta charakterystyki są bardzo rozbieżne, dlatego też wyniki z pozostałych badań analizowane są w zakresie kątów $0^{\circ}-15^{\circ}$.
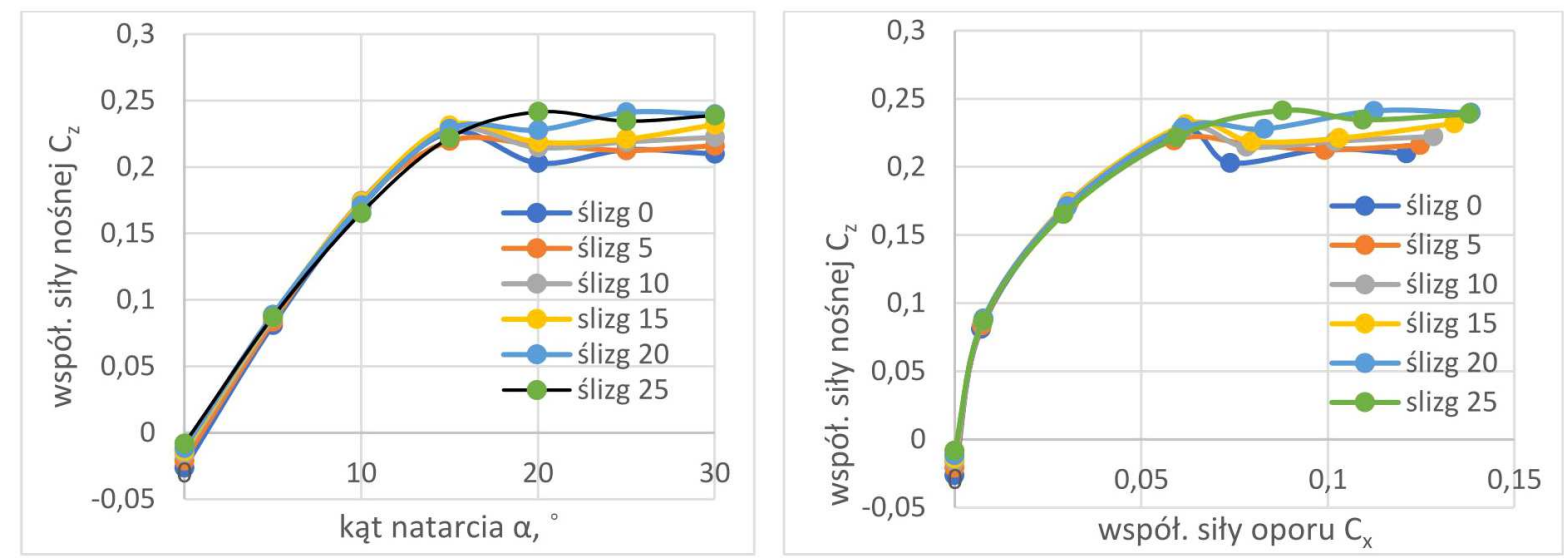

Rys. 14. Zależności $C_{z}(\alpha)$ oraz biegunowa dla konfiguracji płaskiej wg kątów ślizgu

Z wyników badań nad różnymi konfiguracjami stworzono wykresy pozwalające na ilościowe porównanie efektywności sterowania. Szczególną uwagę podczas analizy należy zwrócić na fakt, iż 
nieruchomy turbulizator znajdujący się przy kadłubie montowany był na przeciwnym skrzydle niż reszta generatorów wirów. Z tego względu jego działanie odbywa się w przeciwną stronę. Działanie zaburzaczy odniesione zostało do charakterystyk konfiguracji płaskiej oraz porównane z działaniem konwencjonalnego sterowania.

Rysunek 15 przedstawia charakterystyki przechylenia przy ślizgu $0^{\circ}$ od kąta natarcia. Widać, że współczynniki dla różnicowego wychylenia lotek oraz turbulizatorów leżących dalej od kadłuba, w całym rozpatrywanym zakresie kątów natarcia, są znacznie wyższe niż współczynniki dla konfiguracji płaskiej. W zakresie kątów $0^{\circ}-5^{\circ}$ największą skutecznością odznacza się ruchomy turbulizator. Nieruchomy turbulizator przy kadłubie wraz ze wzrostem kątów natarcia zwiększa swoją efektywność. Na krytycznym kącie natarcia różnica współczynnika przechylenia pomiędzy lotkami a turbulatorami zamontowanymi dalej od kadłuba wynosi 0,0012, natomiast uwzględniając przeciwny kierunek działania turbulizatora przy kadłubie, różnica między lotkami a turbulizatorem 1 wynosi 0,0015 . Na kątach poniżej $3^{\circ}$ turbulizator 1 nie powoduje przechylenia.

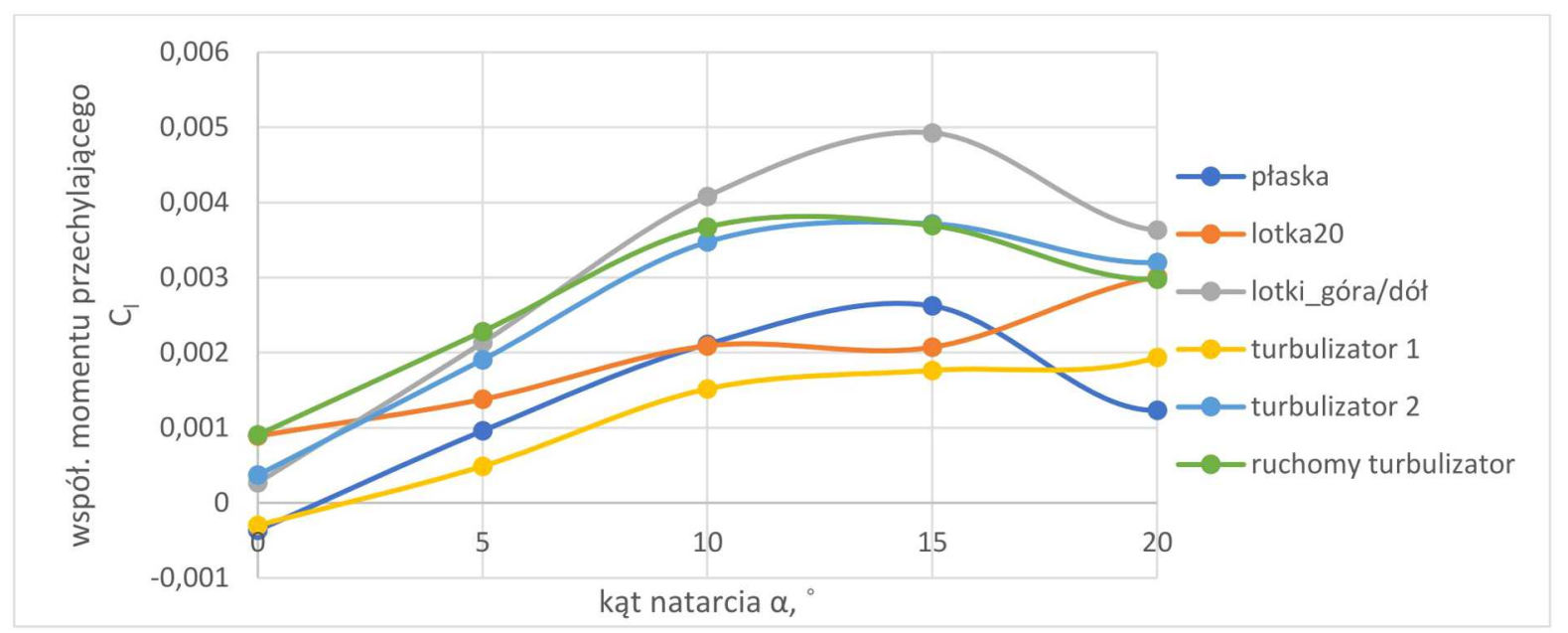

Rys. 15. Charakterystyki $C_{l}(\alpha)$ dla kąta ślizgu $0^{\circ}$

Rysunek 16 przedstawia charakterystyki dla kąta ślizgu $15^{\circ}$. Zauważalny jest tutaj spadek efektywności działania lotek względem ślizgu $0^{\circ}$. Polepsza się natomiast efektywność zaburzaczy. Turbulizator 1 działa na całym zakresie kątów natarcia.

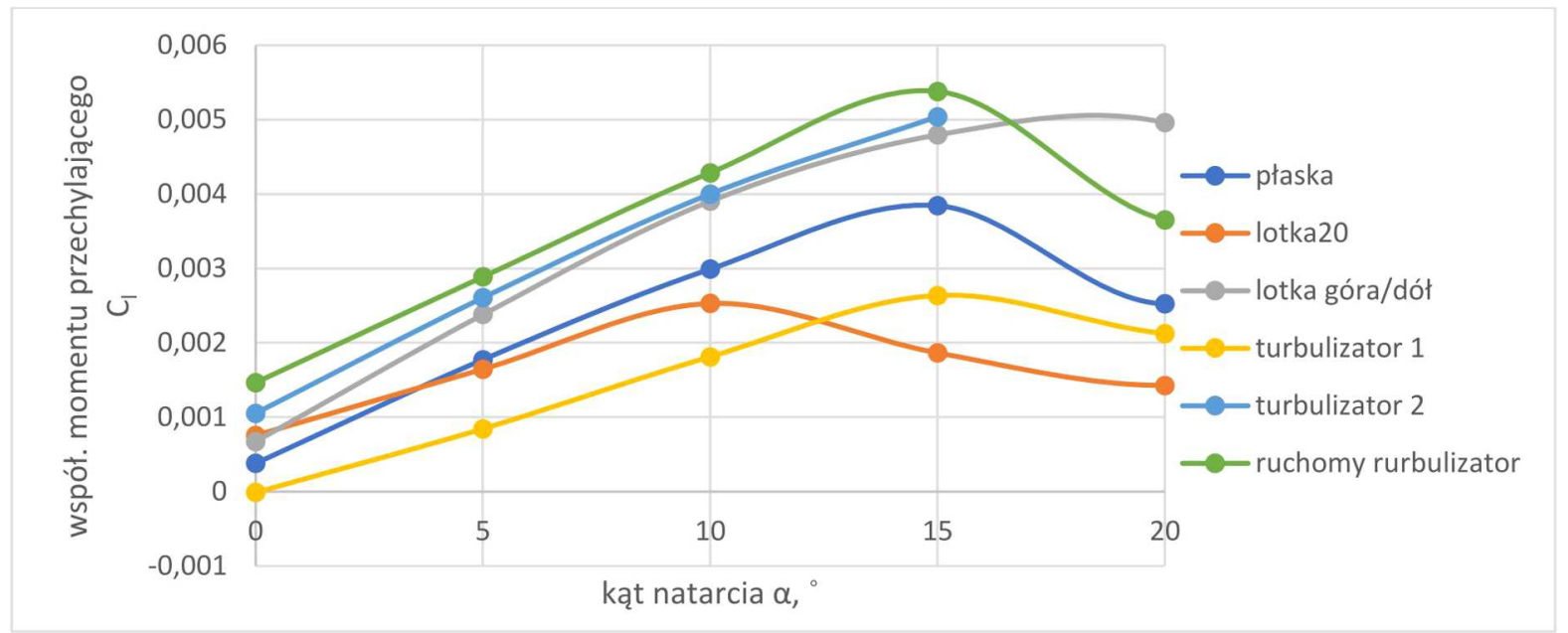

Rys. 16. Charakterystyki $C_{l}(\alpha)$ dla kąta ślizgu $15^{\circ}$ 
Rysunek 17 przedstawia charakterystyki dla kąta ślizgu 25․ Największy przyrost współczynnika względem konfiguracji płaskiej zaobserwować można dla ruchomego turbulizatora. Dla krytycznego kąta natarcia przyrost ten wynosi 0,0015 i jest o 0,0006 większy niż dla lotek. Różnica współczynników pomiędzy konfiguracją płaską a nieruchomym turbulizatorem 1 wynosi 0,0011. Na całym zakresie kątów generatory wirów krawędziowych mają lepszą efektywność niż konwencjonalne sterowanie.

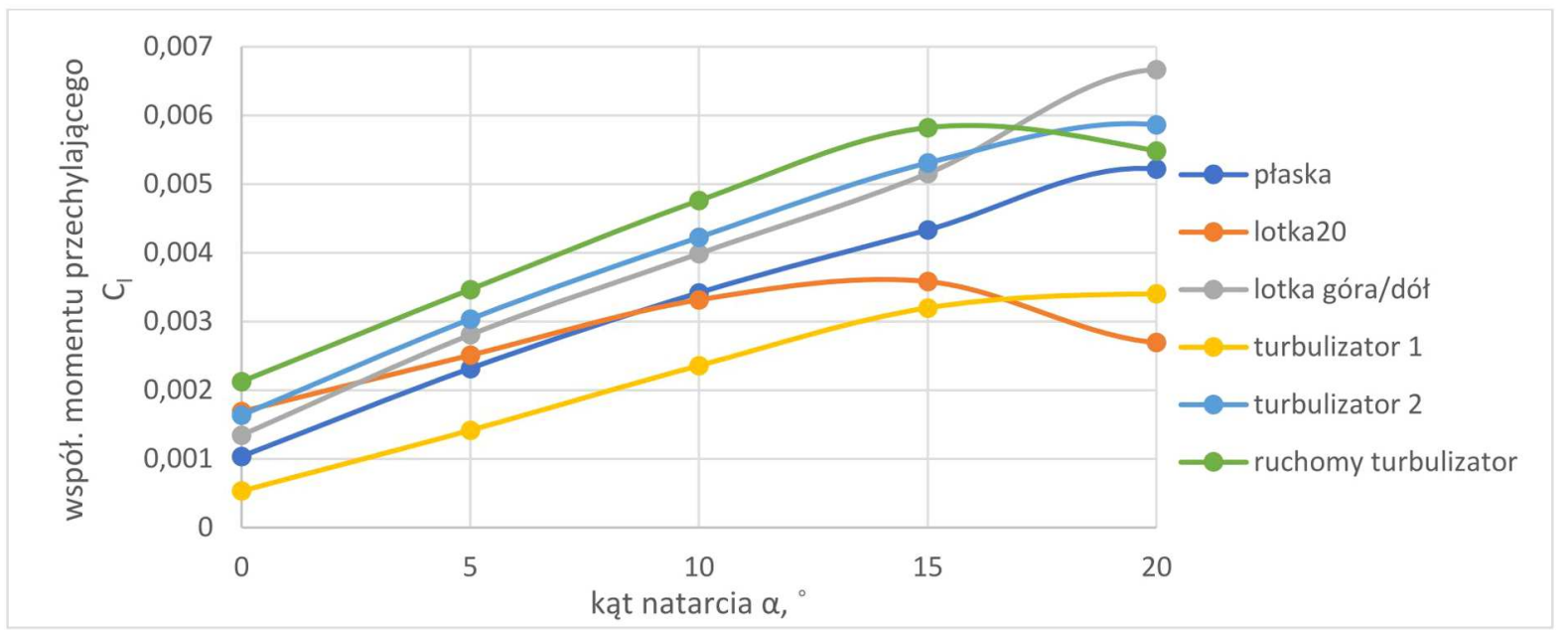

Rys. 17. Charakterystyki $C_{l}(\alpha)$ dla kąta ślizgu $25^{\circ}$

Kolejne trzy wykresy (rys. 18-20) przedstawiają porównanie charakterystyk $C_{n}(\alpha)$. Pierwszy z nich jest dla ślizgu równego $0^{\circ}$. Dla konfiguracji płaskiej występują spore współczynniki odchylenia na lewe skrzydło, turbulizator nieruchomy położony dalej od kadłuba nie ma żadnego wpływu na zmiany odchylenia. W zakresie kątów natarcia $0^{\circ}-5^{\circ}$ turbulizator ruchomy powodował efekt negatywnego odchylenia w stronę przeciwną do przechylenia, efekt ten zaobserwowany został również w całym zakresie turbulatora 1. Spowodowane mogło to zostać oporami wywoływanymi przez elementy zaburzające. Różnicowe wychylenie lotek powodowało odchylenie w kierunku przechylenia.

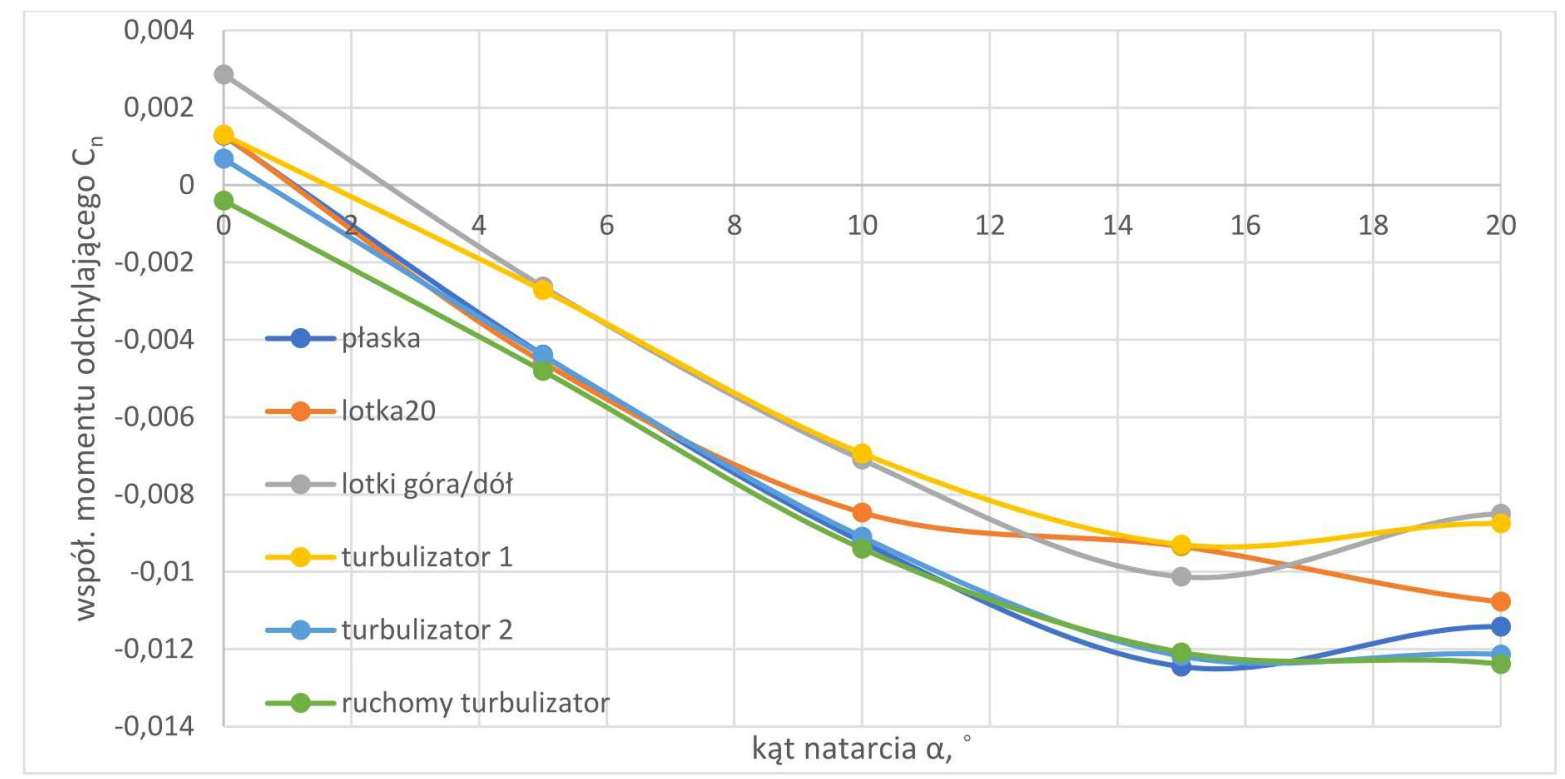

Rys. 18. Charakterystyki $C_{n}(\alpha)$ dla kąta ślizgu $0^{\circ}$ 


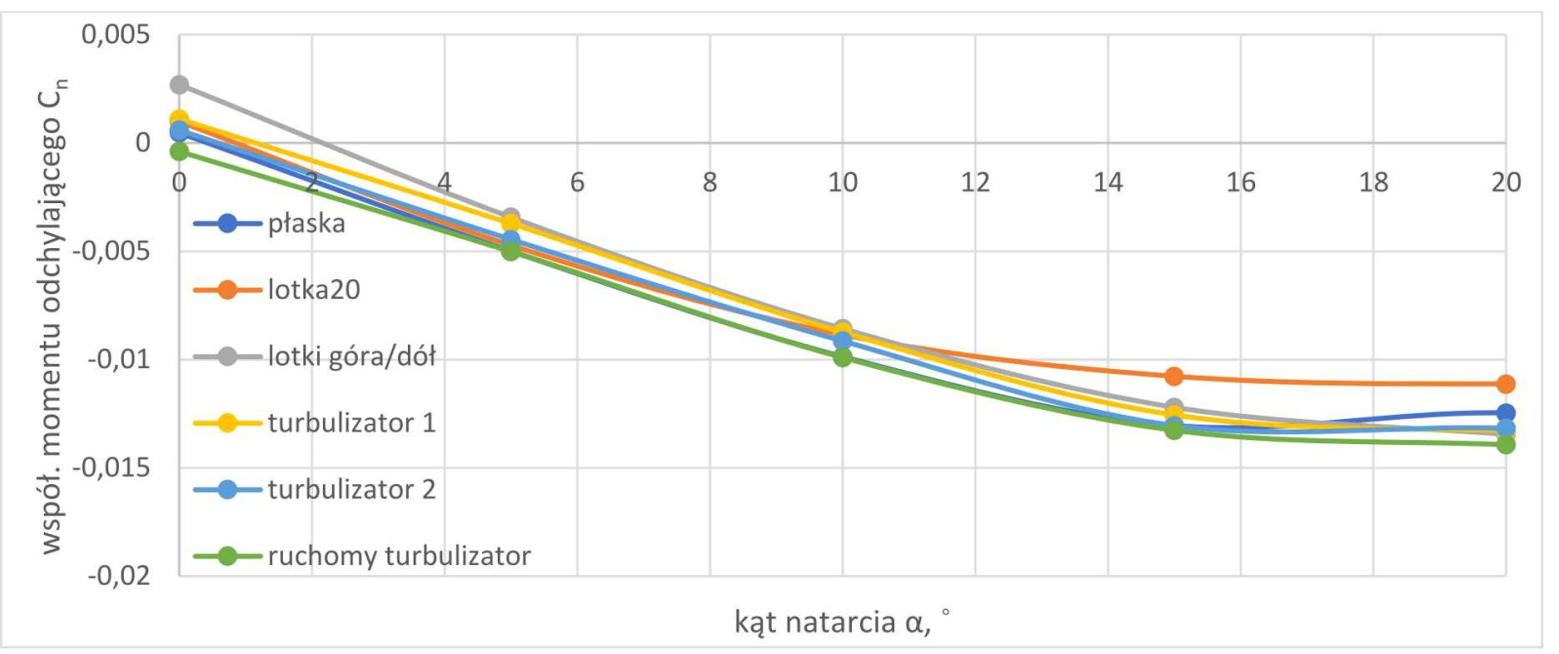

Rys. 19. Charakterystyki $C_{n}(\alpha)$ dla kąta ślizgu $10^{\circ}$

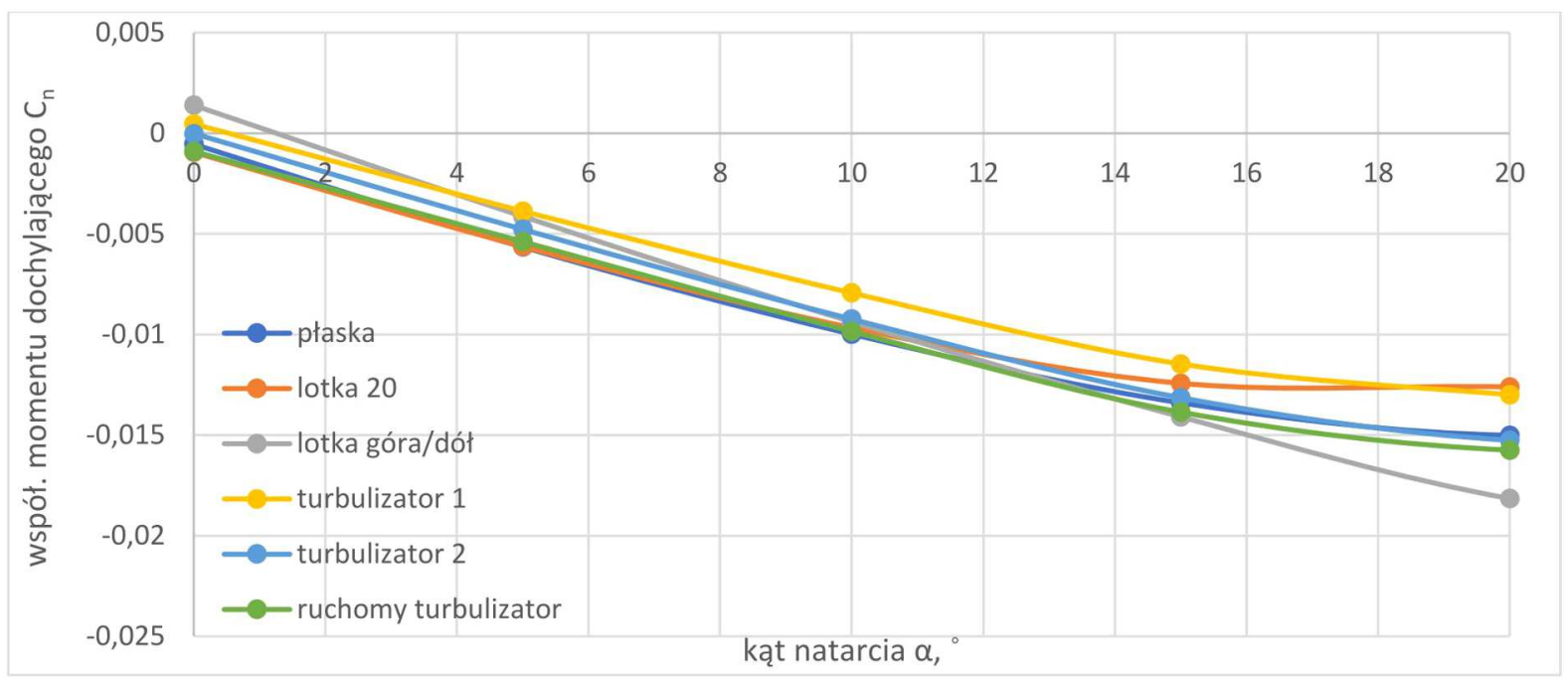

Rys. 20. Charakterystyki $C_{n}(\alpha)$ dla kąta ślizgu $25^{\circ}$

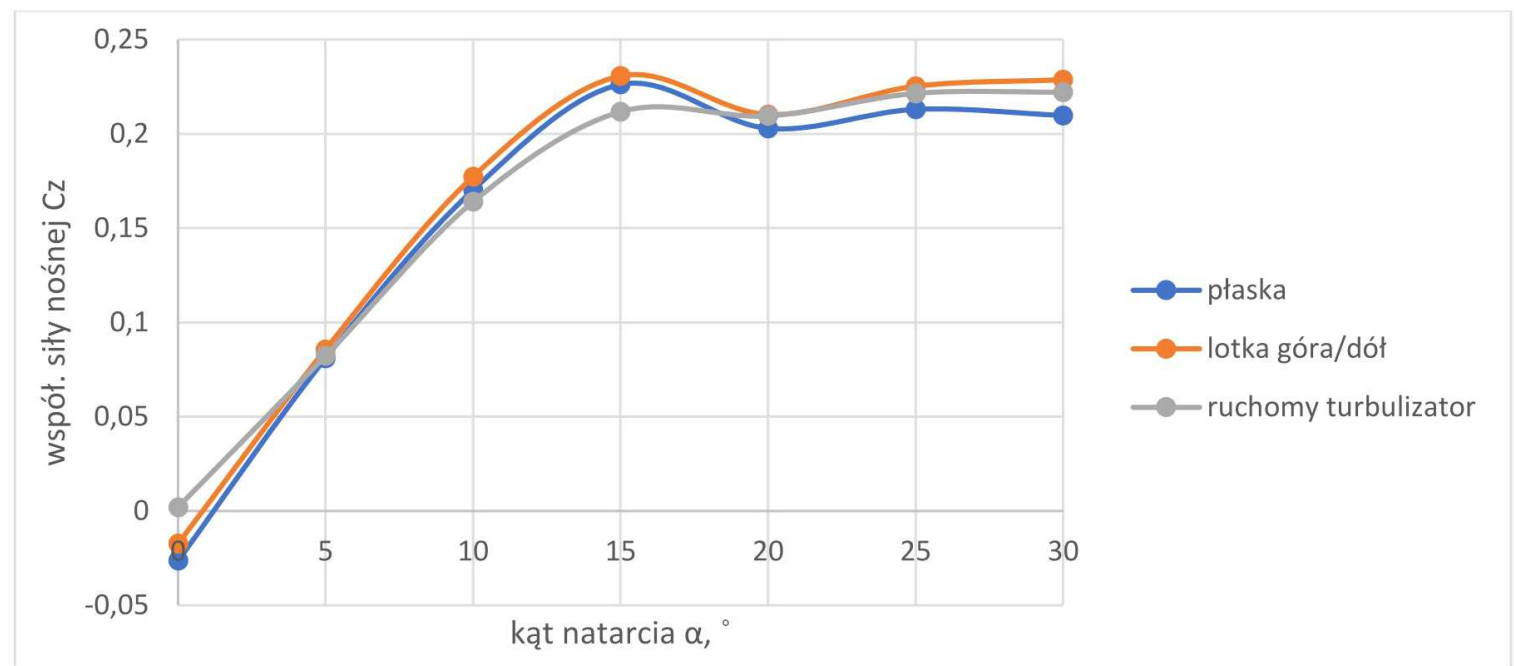

Rys. 21. Charakterystyka $C_{z}(\alpha)$ dla kąta ślizgu $0^{\circ}$ 
Dla ślizgu $10^{\circ}$ niezaobserwowany został negatywny efekt odchylenia wywołany przez zaburzacz nieruchomy zlokalizowany bliżej kadłuba. Zarówno na rys. 19, jak i rys. 20 charakterystyki z wykorzystaniem urządzeń sterujących są zbieżne z charakterystyką konfiguracji płaskiej. Oznacza to, że elementy nie miały wpływu na odchylenie modelu.

$\mathrm{Na}$ wykresie na rys. 21 przedstawiono charakterystyki $C_{z}(\alpha)$. W zakresie kątów natarcia $0^{\circ}$ $5^{\circ}$ siła nośna, z użyciem turbulizatora, wzrosła w stosunku do konfiguracji płaskiej. Sugerować to może, iż tego typu zaburzacz przy wykorzystaniu go na obu skrzydłach jednocześnie służyć może do polepszania charakterystyk modelu.

\section{Podsumowanie}

Z analizy wyników oraz przeglądu literatuy można wyciągnąć przedstawion poniżej wnioski.

- Dla badanego modelu oderwanie następuje na kącie natarcia $15^{\circ}$, a największe współczynniki momentów występują dla kata ślizgu $25^{\circ}$.

- Dla małych kątów ślizgu generatory wirów są nieco mniej efektywne niż różnicowo wychylone lotki, natomiast powyżej kąta ślizgu równego $15^{\circ}$ zaburzacze przewyższają swoją efektywnością konwencjonalne sterowanie. Oznacza to, że sterowanie microsamolotem realizowane może być za pomocą układów turbulizujących o elementach typu makro.

- Najlepsze efekty osiągnięte zostały dla turbulizatorów umieszczonych przy końcówce skrzydła, spowodowane zostało to większym ramieniem, na jakim oddziaływał przyrost siły nośnej wytworzony przez zaburzacze. Różnica współczynników momentów przechylających pomiędzy turbulatorem ruchomym a zaburzaczem z obydwiema powierzchniami wychylonymi jednocześnie jest na tyle niewielka, że warto zastanowić się, czy poniesiony wydatek energetyczny na wywołanie ruchów oscylacyjnych generatora jest współmierny do osiąganych efektów.

- Można spodziewać się, że ruchome turbulizatory po obu stronach skrzydła polepszą charakterystykę $C_{z}(\alpha)$. Wymaga to jednak wykonania dodatkowych badań.

- Należy skrupulatnie określić bilans energetyczny układu, w celu zapewnienia jego działania podczas całego lotu. Jest to o tyle istotne, iż układy takie charakteryzują się większym zapotrzebowaniem energetycznym od układów konwencjonalnych.

Konkludując powyższą pracę stanowiącą o zagadnieniu sterowania przepływem, stwierdzić można, że problematyka sterowania opływem obiektu jest jednym z ważniejszych celów poznawczych w obecnie prowadzonych pracach badawczych. Zainteresowanie możliwością zmiany charakterystyk obiektu za pomocą wpływania na warstwę przyścienną związane jest głównie z możliwością zmniejszenia oporu aerodynamicznego statku powietrznego, co powiązane jest z ograniczeniem zużycia paliwa i poprawą osiągów. W pracy przedstawiono analizę efektywności działania aktywnie sterowanych generatorów wirów krawędziowych w postaci powierzchni zabudowanych na górnej części płata dla modelu o skrzydle prostokątnym. Z otrzymanych wyników wynikło, że zastosowanie zaburzaczy przepływu powoduje generowanie momentów sterujących o wartościach zbliżonych do otrzymywanych podczas używania lotek. Istnieje więc możliwość zastosowania tego typu układów, w celu zastąpienia konwencjonalnych systemów sterowania. Wiąże się to z wieloma pozytywnymi następstwami, m.in. zmniejszeniem stałych czasowych układu sterowania lotem, poprzez umiejscowienie elementów sterujących w przedniej części profilu oraz możliwością aktywnej regulacji wytwarzanych momentów. Przedstawione koncepcje wymagają jednak jeszcze wielu badan, aby udało się optymalnie wykorzystać zawarty w nich potencjał.

Na kierunek dalszych eksperymentów warto byłoby obrać temat wpływu położenia bariery mechanicznej względem krawędzi natarcia oraz sprawdzić zależność pomiędzy wysokością, wysunięciem barier a powstającymi siłami aerodynamicznymi. Efektywność układów turbulizujących może ulec zmianie także dla różnych skosów skrzydła. 


\section{Bibliografia}

1. Etkin B., Reid L., Dynamics of Flight Stability and Control, John Wiley \& Sons, Toronto, 1996

2. Ostapkowicz P., Analiza koncepcji sterowania lotem bezzałogowych modeli latających typu MAV z wykorzystaniem urządzeń manewrowych umieszczonych na krawędzi natarcia skrzydła, Prace Instytutu Lotnictwa, 216, 126-145, Warszawa, 2011

3. Wygodzka K., Praca magisterska: Badanie efektywności sterowania samolotem za pomoca wirów krawędziowych, Politechnika Wrocławska, Wydział Mechaniczno-energetyczny, Wrocław, 2020, niepublikowane

4. KRZYSiAK A., Zastosowanie nowego rodzaju strumieniowych generatorów wirów do sterowania przepływem, Prace Instytutu lotnictwa, 212,3-36, Warszawa, 2011

5. Moghaddam1 T., Neishabouri N., On the active and passive flow separation control techniques over airfoils, IOP Conf. Series: Materials Science and Engineering, 248, 2017

6. Ostapkowicz P., Koncepcje rozwiązań wibracyjnych urządzeń manewrowych do sterowania lotem bezzałogowych modeli latajacych typu MAV, Prace Instytutu Lotnictwa, 216, 146-167, Warszawa, 2011

7. Gosiewski Z., Mystkowski A., Ostapkowicz P., Kulesza Z., Łukaszewicz A., KoszewNIK M., Kondratiuk M., Autonomiczny, zintegrowany system rozpoznania wykorzystujacy autonomiczne platformy klasy mikro, Sprawozdanie z realizacji zadania: Opracowanie koncepcji sterowania mikrosamolotem za pomocą generacji wirów krawędziowych, str. 1, 57-69, Politechnika Białostocka, 2009

8. https://www.mub.eps.manchester.ac.uk/science-engineering/2019/05/14/how-goingflapless-couldrevolutionise-air-travel/ [dostęp: 27.07.2020]

9. https://www.c4isrnet.com/unmanned/2019/05/06/stealthy-flapless-drone-steers-withvectoredthrust/ [dostęp: 27.07.2020]

10. https://newatlas.com/worlds-first-flapless-aircraft-maiden/59524/\#gallery:2?itm_source= newatlas\&itm_medium=article-body [dostęp: 27.07.2020]

11. Cook M., Buonanno A., Erbslöh S., A circulation control actuator for flapless flight control, Aeronautical Journal, August, 2008

12. Blockley R., Shyy W., Encyclopedia of Aerospace Engineering: Fluid Dynamics and Aerothermodynamics, John Wiley \& Sons, 2010

13. Gronczewski A., Tunel wodny model 2436 firmy Rolling Hills Research Corporation, Politechnika Wrocławska, Wydział Mechaniczno-Energetyczny, Wrocław, 2010

14. http://airfoiltools.com/airfoil/details?airfoil=df101-il [dostęp: 27.07.2020]

15. Garbowski M., Sibilbki K., Stacjonarne i niestacjonarne badania mikrosamolotu w płaszczyznach pochylenia, przechylenia i odchylenia z wykorzystaniem tunelu wodnego, Modelowanie Inżynierskie, 44, 65-73, Gliwice, 2012

\section{Lateral control of unmanned aerial vehicle using boundary layer disruptors}

In the paper, the concept of lateral control of an unmanned aerial vehicle (UAV) using boundary layer turbulizers was presented. A review of the current state of knowledge on the methods of generating edge vortices was carried out and mechanical turbulators were developed for the rectangular wing's UAV. The results of experimental tests conducted in a water tunnel for models equipped with vortex generators systems with active and passive elements were disscused. Possible further directions for the development of research on unconventional methods of aircraft control are proposed. 